\title{
HMGA1 variant IVS5-13insC is associated with insulin resistance and type 2 diabetes: an updated meta-analysis
}

\author{
Yancheng Liu ${ }^{1}$, Liting Zheng ${ }^{1,2}$, Hao Kong ${ }^{1}$, Qinglu Wang ${ }^{1}$, Xuewen Tian ${ }^{3}$
}

1. Key Laboratory of Biomedical Engineering \& Technology of Shandong High School, Qilu Medical University, Zibo, 255213, China.

2. Department of Vascular, Thyroid and Breast Surgery, Affiliated Hospital of Guangdong Medical University, Zhanjiang, 524000, China.

3. Sports Science Research Center of Shandong Province, Jinan, 250102, China.

\begin{abstract}
:
Background: High-mobility group A1 (HMGA1) polymorphism has been suspected as a gene variant associated with type 2 diabetes (T2D). However, conflicting outcomes have been reported.

Objective: This meta-analysis aimed to predict the association between the HMGA1 variant IVS5-13insC and T2D.

Methods: Statistical analyses were performed using Stata/SE 12.0 software.

Results: A total of 11 case-control studies in 6 articles were included. Results suggested that the HMGA1 variant IVS5-13insC was associated with an increased risk of insulin resistance $(\mathrm{OR}=0.61,95 \% \mathrm{CI} 0.56$ to $0.66, \mathrm{P}<0.0001), \mathrm{T} 2 \mathrm{D}(\mathrm{OR}=0.67,95 \%$ CI 0.61 to $0.73, \mathrm{P}<0.0001$ ), particularly for Caucasians with increased risks of T2D (OR $=0.56,95 \%$ CI 0.49 to $0.65, \mathrm{P}<$ 0.0001) compared with wild-type subjects.

Conclusion: This meta-analysis indicated that the HMGA1 variant IVS5-13insC can be a risk factor of T2D development, particularly among Caucasians. Significant risks were also found (Asian: OR $=0.74,95 \%$ CI: 0.63 to 0.86, P < 0.0001, Hispanic-American: $\mathrm{OR}=0.81,95 \%$ CI: 0.65 to $1.01, \mathrm{P}<0.0001)$ in non-Caucasian population. However, ethnical studies should be conducted to reveal whether the HMGA1 variant IVS5-13insC is associated with an increased risk of T2D.
\end{abstract}

Keywords: HMGA1, type 2 diabetes, insulin resistance, variant, meta-analysis.

DOI: https://dx.doi.org/10.4314/ahs.v18i4.4

Cite as: Liu Y, Zheng L, Kong H, Wang Q, Tian X. HMGA1 variant IVS5-13insC is associated with insulin resistance and type 2 diabetes: an updated meta-analysis. Afri Health Sci. 2018;18(4): 865-872. https:// dx.doi.org/10.4314/ahs.v18i4.4

\section{Introduction}

Type 2 diabetes (T2D) is one of the major and exacerbating health problems worldwide; T2D is predicted to affect 490 million in $2030^{1}$. Strong genetic influences and many polymorphisms have been reproducibly associated with $\mathrm{T} 2 \mathrm{D}^{2,3}$. Insulin resistance in muscle, liver, and adi- pose tissues is a primary characteristic of most patients with T2D; as such, these tissues become resistant to endogenous and exogenous insulin. The interaction of insulin with target tissues is mediated by insulin receptor (INSR), a glycoprotein implicated in directing insulin to target cells and initiating cell responses to insulin ${ }^{4}$.

High-mobility group A1 (HMGA1) is an architectural transcription factor involved in numerous biological functions in the nucleus, including regulation of DNA replication, transcription, recombination, and repair; among these functions, transcriptional regulation of gene expression is considered as the most important. After HMGA1 binds to DNA, HMGA1 can be polymerized with other transcription factors, forming an "en-

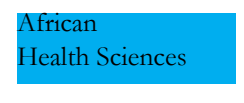

(C) 2018 Liu et al. Licensee African Health Sciences. This is an Open Access article distributed under the terms of the Creative commons Attribution License (https://creativecommons.org/licenses/BY/4.0), which permits unrestricted use, distribution, and reproduction in any medium, provided the original work is properly cited. 
hanceosome" to regulate gene transcription; thus, gene expressions are positively or negatively regulated ${ }^{5}$. Studies on humans and knockout mice have suggested that HMGA1 is involved in T2D pathogenesis through the regulation of INSR gene expression; INSR gene expression is decreased by functional HMGA1 gene variants ${ }^{6}$. HMGA1-deficient patients have been biologically investigated because of their clinical value. However, whether HMGA1 single gene deletion- or mutation-induced insulin resistance is the underlying cause of T2D remains unknown.

Low-frequency insertion polymorphism IVS5-13insC (c.136-14_136-13insC) has been identified and associated with insulin resistance and T2D among individuals of white European ancestry and Chinese populations ${ }^{7,8}$. However, no similar association is observed in another study involving Caucasians and populations of African and Hispanic descent ${ }^{9,10,11}$. Furthermore, conflicting results regarding the association of HMGA1 with T2D and insufficient data on diverse ethnic groups have caused difficulty in performing clinical translation of HMGA1 IVS5-13insC genotyping.

Results regarding the functional effect of the HMGA1 IVS5-13insC variant are also contradictory. On one hand, HMGA1 and INSR expressions decrease in diabetic carriers of IVS5-13insC compared with those of wild-type diabetic and non-diabetic patients ${ }^{8}$. INSR protein expression and insulin-binding capacity are also restored in lymphoblasts obtained from diabetic IVS5-13insC carriers through HMGA1 DNA transfection. On the other hand, IVS5-13insC does not affect HMGA1 or INSR expression in adipose tissues of normoglycemic patients ${ }^{11}$. IVS5-13insC is present at position 13 of HMGA1 exon 6; however, the direct mechanism by which this variant affects mRNA expression or amino acid sequence remains unclear.

A previous meta-analysis of Caucasians focused on this issue and arrived at a negative conclusion ${ }^{11}$. Thus, we performed a meta-analysis of eligible case-control studies worldwide to investigate whether the HMGA1 variant IVS5-13insC is associated with an increased risk of in- sulin resistance and T2D. We also conducted sub-group analyses according to different ethnicities to explore the presence of ethnicity-specific effects.

\section{Materials and methods \\ Literature search strategy}

We searched Pubmed, EMBASE, and Web of science. The last updated search was performed on June 30, 2017. We used any possible combinations of relevant keywords: "HMGA1 or high-mobility group A1," "polymorphism or mutation or mutant or variant," and "insulin resistance, T2D, or type 2 diabetes."

Articles describing the relationship between T2D and IVS5-13insC were identified with only published studies in English. The inclusion criteria were set as follows: (a) evaluation of IVS5-13insC, insulin resistance, and T2D risk and (b) case-control design to estimate odds ratio (OR) with a 95\% confidence interval (CI). Articles were excluded according to the following criteria: (a) reviews, meta-analyses, and other non-case-control studies and (b) non-human studies. For studies with the same or overlapping data by the same authors, the most suitable studies with the largest number of cases or latest publication dates were selected. The searching was also supplemented by retrieving additional studies from selected article's references and citations and from the pubmed option related articles.

\section{Data extraction}

Two reviewers (Yancheng Liu and Liting Zheng) independently extracted information from all of the eligible publications and reached consensus on all items. A third author (Hao Kong) was invited to assess articles in case of disagreement. The following information was extracted from each article: first author, journal, year of publication, country of origin, ethnicity, and exact data of cases and controls.

\section{Quality assessment}

The Newcastle-Ottawa Scale (NOS) was used to assess the methodological quality of included studies. As quite comprehensive and partly validated, the NOS, a starbased system allowing a semi-quantitative assessment of non-randomized study quality, consists of eight items 
and takes into consideration three major parameters, including selection of participants, comparability of study groups, and exposure. The scale ranges from 0 to 9stars, with more stars indicating a higher quality study ${ }^{12}$.

\section{Statistical analysis}

The T2D risk associated with IVS5-13insC was evaluated using ORs with a 95\% CI. Heterogeneity (I2) was evaluated using a Cochran's Q statistic to assess the degree of inter-study variation. The pooled OR of each study was calculated using a fixed-effects model when no statistically significant heterogeneity was detected with a $\mathrm{P}$ value $<$ 0.10. A random-effects model was used when significant heterogeneity was found.

The statistical significance of the pooled ORs was determined using a $\mathrm{Z}$ test. $\mathrm{P}$ value $<0.05$ was considered significant. A stratified analysis of ethnicity and continent was also performed: (1) Caucasian and non-Caucasian and (2) Asian and European. Egger's plot was used to evaluate the probability of publication bias. Statistical analyses were carried out using Stata/SE 12.0 for Windows.

\section{Results}

\section{Characteristics of the studies}

Figure 1 demonstrates the progress of the article selection. After initially searching PubMed, EMBASE, and Web of science, we identified 52 publications. Of these 52 publications, 34 were excluded after titles and abstracts were scanned to determine whether or not these articles are relevant to T2D and HMGA1 polymorphism; as a result, 18 articles were considered for further assessment. Of these 18 articles, 11 were not related to the HMGA1 variant IVS5-13insC; thus, these articles were removed from the list. After reading the full text of the 7 remaining studies, we excluded 1 article that did not compare between T2D patients and healthy controls. As a result, 11 case-control studies from 6 articles $(5$ articles about T2D7,8,9,10,11 and 1 article about MetS13) were included in our meta-analysis. Selected studies were primarily conducted in Europe, Asia, and South America. Reports from other areas were limited. We estimated the risk between T2D and control groups by comparing gene frequencies of the HMGA1 variant IVS5-13insC (del/ins, ins/ins) and the wild type (del/del).

\section{2 articles were identified in initial searching of pubmed EMBASE and Web of science Keywords: Type 2 diabetes, insulin resistance and HMGA1}

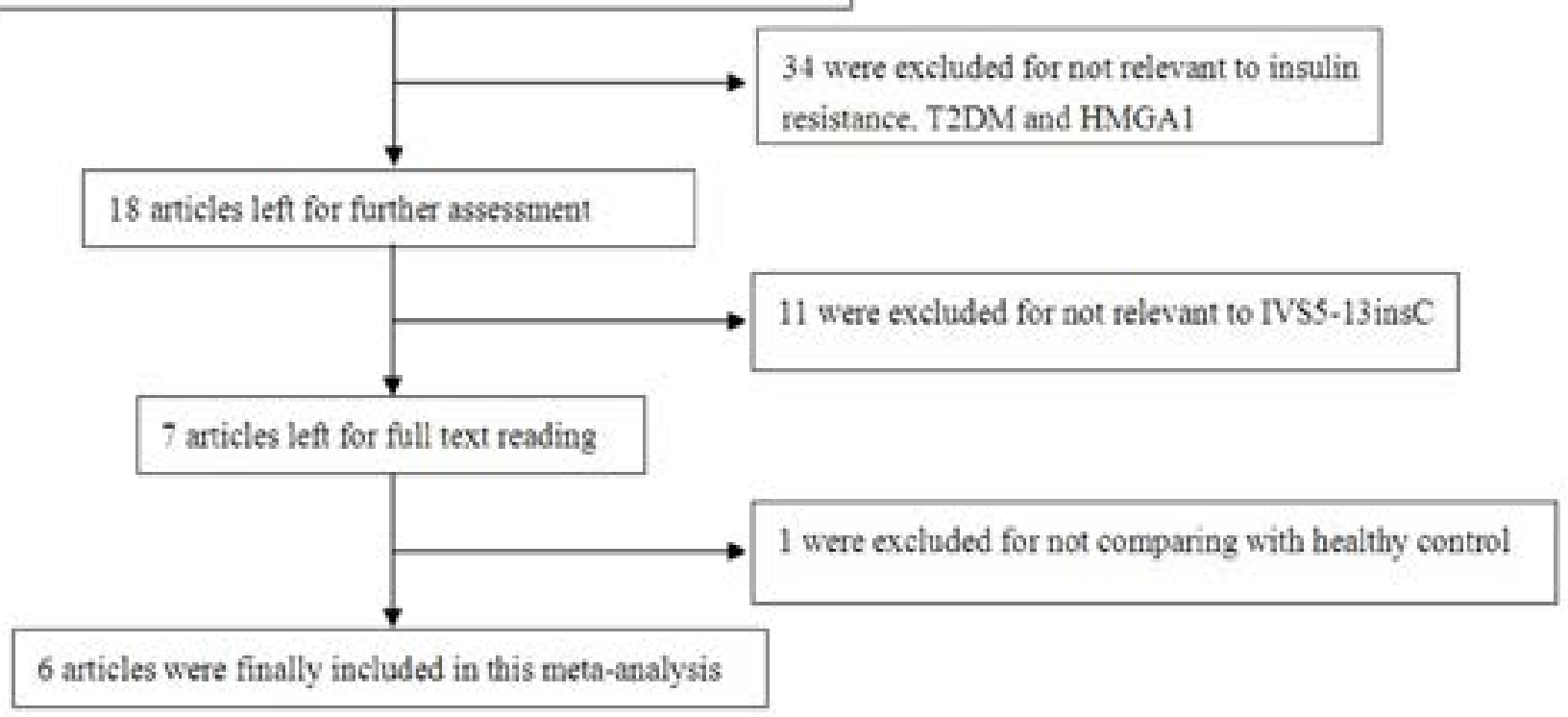

Fig. 1 Flow diagram of included/excluded studies 
According to the NOS, overall quality ratings of the studies ranged from 5 to 8 , with a median NOS score of 7 . A dominant genetic model was adopted on the basis of previous observations indicating that: no statistical difference in results was observed between dominant and additive models. We preferentially used adjusted ORs reported by the authors. If no adjusted estimates were presented, we included the crude estimate. The pooled-effects estimates were used to combine values from the single studies and were expressed as OR and the related 95\% CI. The detailed information of each study is shown in Table 1.

Table 1 Characteristics of the11 case-controls included in the meta-analysis

\begin{tabular}{|c|c|c|c|c|c|c|c|c|c|c|}
\hline \multirow{2}{*}{$\begin{array}{l}\text { First author } \\
\text { (years) }\end{array}$} & \multirow{2}{*}{ Disease } & \multirow[t]{2}{*}{ Country } & \multirow[t]{2}{*}{ Ethnicity } & \multicolumn{2}{|c|}{ Non-diabetic patients genotype } & \multicolumn{2}{|c|}{ Diabetic patients genotype } & \multirow[t]{2}{*}{ Model } & \multirow{2}{*}{$\begin{array}{l}\text { Adjusted RR/OR } \\
\text { estimate }(95 \% \mathrm{Cl})\end{array}$} & \multirow[t]{2}{*}{ Quality score } \\
\hline & & & & $\begin{array}{l}\text { Mutant type } \\
\text { (c/c or c/-) }\end{array}$ & Wild type (-/-) & $\begin{array}{l}\text { Mutant type (c/c } \\
\text { or } \mathrm{c} /-)\end{array}$ & Wild type (-/-) & & & \\
\hline $\begin{array}{l}\text { Pullinger } \\
\text { (2014) }\end{array}$ & T2D & America & $\begin{array}{l}\text { Hispanic- } \\
\text { American }\end{array}$ & 293 & 531 & 135 & 185 & Dominant model & $1.44(1.09-1.90)$ & 7 \\
\hline & & & & & & & & Additive model & $1.27(1.01-1.58)$ & - \\
\hline \multirow[t]{3}{*}{$\begin{array}{l}\text { Karnes } \\
\text { (2013) }\end{array}$} & $\mathrm{T} 2 \mathrm{D}$ & America & $\begin{array}{l}\text { Hispanic- } \\
\text { American }\end{array}$ & 45 & 597 & 69 & 868 & Dominant model & $0.79(0.49-1.25)$ & 5 \\
\hline & & & $\begin{array}{l}\text { African- } \\
\text { American }\end{array}$ & 6 & 147 & 6 & 210 & Dominant model & $1.51(0.48-4.74)$ & 5 \\
\hline & & & Caucasian & 18 & 475 & 17 & 591 & Dominant model & $0.95(0.44-2.06)$ & 5 \\
\hline $\begin{array}{l}\text { Chiefari } \\
(2013)\end{array}$ & MetS & Italian & Caucasian & 195 & 4821 & 299 & 3106 & Dominant model & $2.42(2.00-2.92)$ & 8 \\
\hline $\begin{array}{l}\text { Chiefari } \\
(2013)\end{array}$ & MetS & Turkish & Caucasian & 57 & 703 & 72 & 587 & Dominant model & $1.66(1.15-2.39)$ & 8 \\
\hline \multirow[t]{2}{*}{ Liu (2012) } & $\mathrm{T} 2 \mathrm{D}$ & China & Asian & 354 & 2358 & 436 & 2139 & Dominant model & $1.34(1.15-1.56)$ & 8 \\
\hline & & & & & & & & Additive model & $1.34(1.16-1.55)$ & - \\
\hline $\begin{array}{l}\text { Marquez } \\
(2012)\end{array}$ & $\mathrm{T} 2 \mathrm{D}$ & France & Caucasian & 228 & 4159 & 267 & 4639 & Dominant model & $1.07(0.84-1.37)$ & 7 \\
\hline $\begin{array}{l}\text { Chiefari } \\
\text { (2011) }\end{array}$ & $\mathrm{T} 2 \mathrm{D}$ & Italy & Caucasian & 11 & 2533 & 237 & 3041 & Dominant model & $15.7(8.57-29.03)$ & 8 \\
\hline $\begin{array}{l}\text { Chiefari } \\
\text { (2011) }\end{array}$ & $\mathrm{T} 2 \mathrm{D}$ & America & Caucasian & 45 & 913 & 75 & 895 & Dominant model & $1.64(1.05-2.57)$ & 8 \\
\hline $\begin{array}{l}\text { Chiefari } \\
\text { (2011) }\end{array}$ & $\mathrm{T} 2 \mathrm{D}$ & France & Caucasian & 0 & 50 & 27 & 327 & Dominant model & - & 8 \\
\hline
\end{tabular}

MetS: The metabolic syndrome is a common multicomponent disorder where insulin resistance is associated with an increased risk for type 2 diabetes (T2D), hypertension, dyslipidemia, and cardiovascular disease (CVD)

\section{Overall meta-analysis and sub-group analysis}

A summary of the meta-analysis of the HMGA1 variant IVS5-13insC and T2D is shown in Figure 2. The HMGA1 variant IVS5-13insC was significantly associated with an increased risk of insulin resistance and T2D compared with that of healthy controls in overall populations (insulin resistance: $\mathrm{OR}=0.61,95 \% \mathrm{CI} 0.56$ to $0.66, \mathrm{P}<0.0001$; T2D: $\mathrm{OR}=0.67,95 \%$ CI 0.61 to 0.73 , $\mathrm{P}<0.0001$ ), and high heterogeneity (insulin resistance: $\mathrm{I} 2=91.3 \%$; T2D: $\mathrm{I} 2=91.7 \%$ ). 

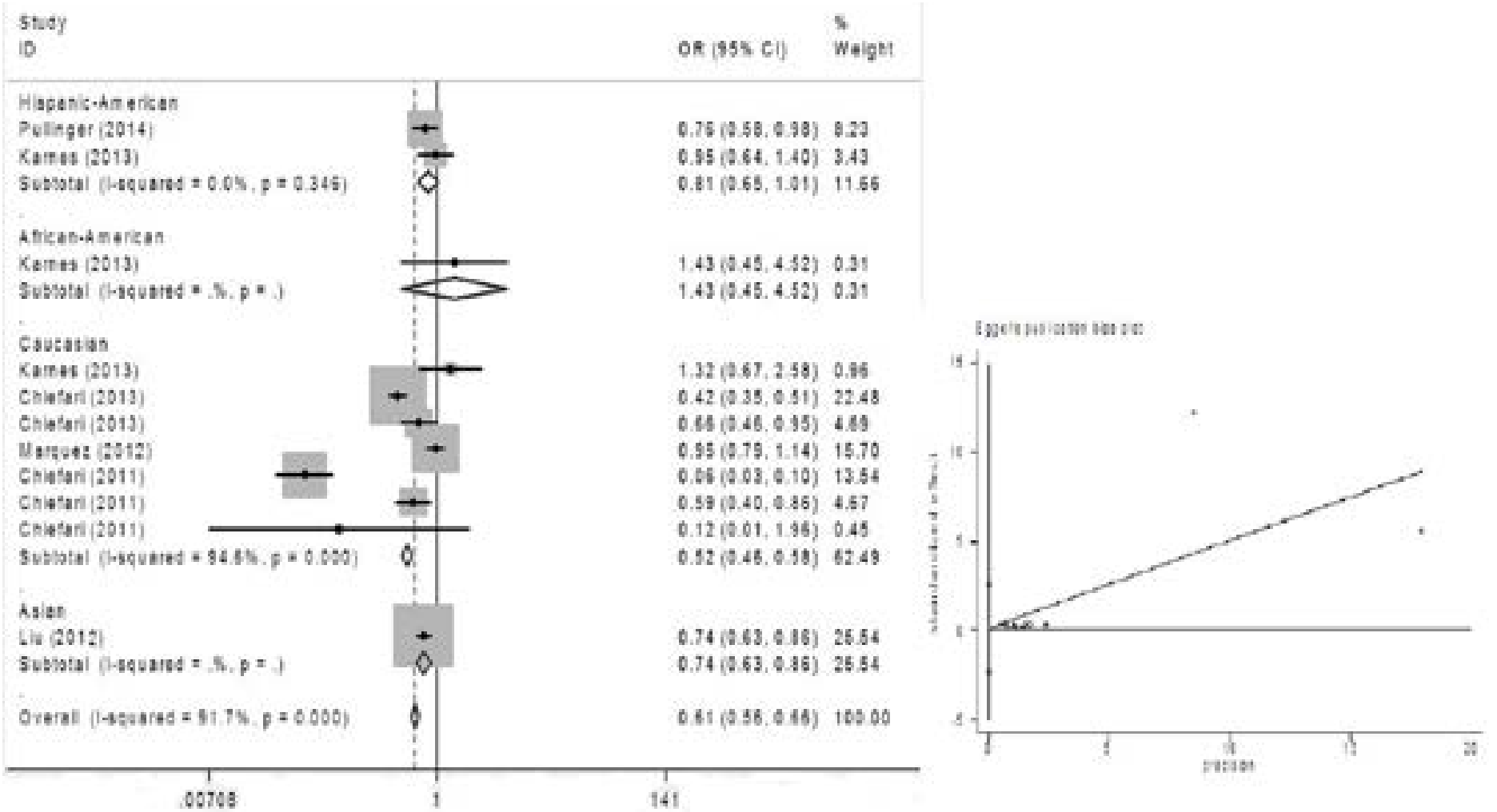

Fig. 2 Meta-analysis of the HMGA1 variant IVS5-13insC and T2D

Sub-group analysis was performed according to different ing pattern was observed in non-Caucasian populations ethnic groups in this meta-analysis. Significant associations were found in Figure 3 (OR $=0.56,95 \%$ CI: 0.49 to $0.65, \mathrm{P}<0.0001)$ in the Caucasian population; an increas- $<0.0001)$.

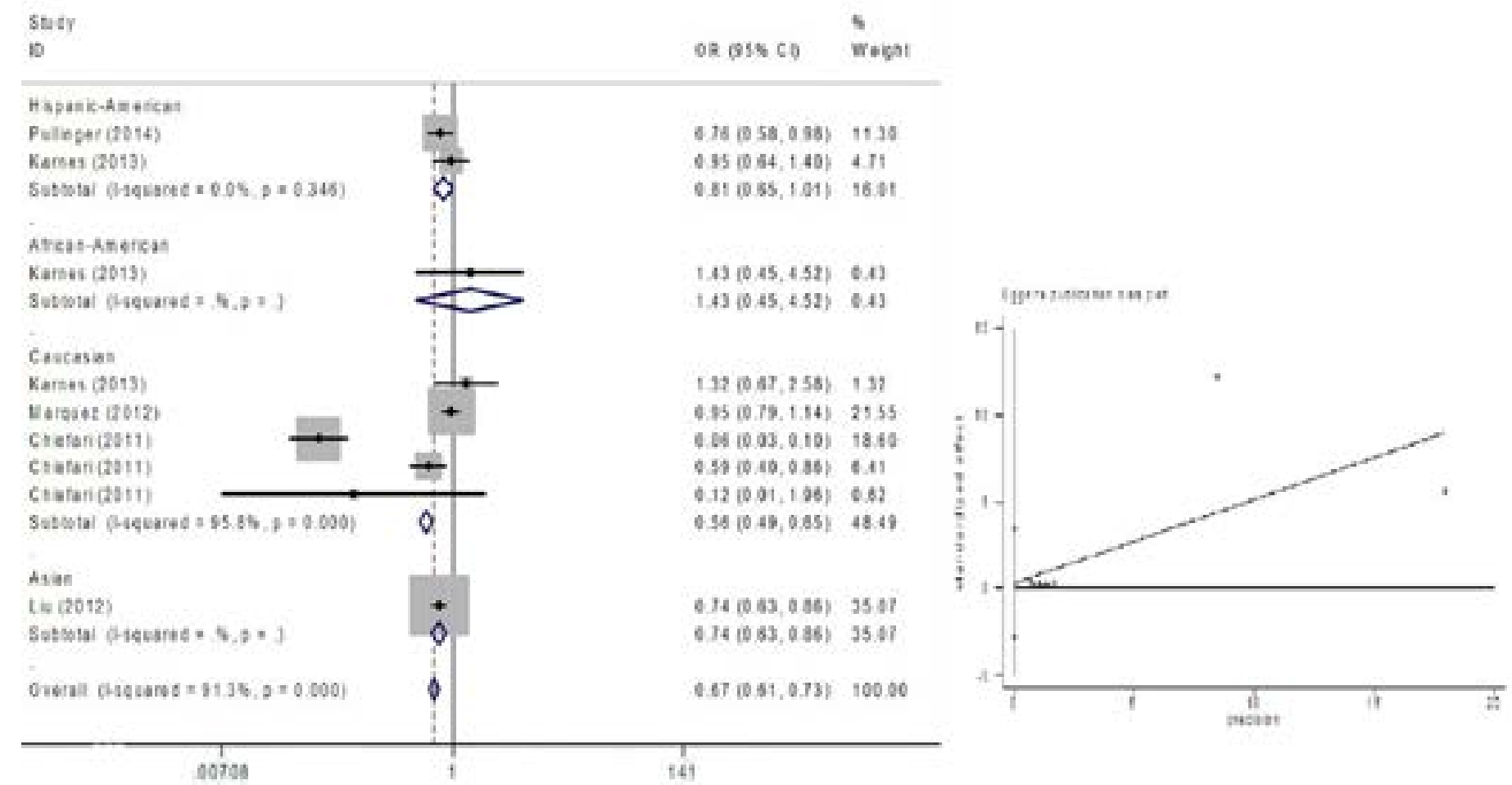

Fig.3 Subgroup meta-analysis of different ethnic groups 


\section{Publication bias}

Egger's test revealed a consistent outcome. Egger's plot indicated a lack of publication bias.

\section{Discussion}

This meta-analysis identify the increased T2D vulnerability of the HMGA1 variant IVS5-13insC variant carriers; our results suggested that the HMGA1 variant IVS5-13in$\mathrm{sC}$ variant is likely involved in T2D pathogenesis. However, a previous meta-analysis of Caucasians revealed that the HMGA1 variant IVS5-13insC is not associated with T2D11. Recently, a meta-analysis of Caucasians and other populations showed that the HMGA1 variant IVS5-13in$\mathrm{sC}$ may increase the prevalence of $\mathrm{T} 2 \mathrm{D}^{14}$. Compared with this meta-analysis, our meta-analysis added two sets of data from an article about MetS in order to analyze the association between the HMGA1 variant and insulin resistance. Our meta-analysis showed the same conclusion that the HMGA1 variant IVS5-13insC may increase insulin resistance and the prevalence of T2D. Furthermore, the HMGA1 variant IVS5-13insC may increase the prevalence of T2D in other ethnic groups.

Genome-wide association studies (GWAS) on patients with T2D have identified associations between polymorphisms and mutations in some genes ${ }^{15}$. These genes have been regarded as potential T2D risk factors. However, current GWAS failed to detect an association between the HMGA1 variant IVS5-13insC and the presence of T2D. To the best of our knowledge, future meta-analyses that include GWAS datasets will help determine whether the IVS5-13insC shows a consistent association with T2D.

The limitations of our study are as follows. First, only published studies in English were included in our data analysis; other languages or unpublished materials could have been overlooked. Second, majority of the studies involved Caucasian populations, whereas four studies focused on non-Caucasian populations. Thus, further studies on other populations should be conducted to investigate such association among non-Caucasian populations. Third, the ORs obtained using comparison models were unadjusted; a precise analysis should be conducted if individual raw data were available. Finally, two meta-analyses indicated significant heterogeneity. Despite these restrictions, our study provided a comprehensive under- standing of the association between the HMGA1 variant IVS5-13insC and risk of T2D.

\section{Conclusion}

The HMGA1 variant IVS5-13insC can be regarded as a new risk factor of the development of insulin resistance and T2D, particularly among Caucasians. Furthermore, Asian and Hispanic-American ethnic groups fail to indicate ethnic diversity of disease susceptibility. In the future, case-control investigations of many ethnic groups and communities should be performed to reveal whether the HMGA1 variant IVS5-13insC is associated with an increased risk of T2D and to determine ethnicity-specific effects.

HMGAl plays a crucial role in blood sugar balance as a structural transcription factor. We believe that an individual with the HMGA1 variant IVS5-13insC has clinical implications. First, the presence of these variants can serve as an early predictive marker of both insulin resistance and T2D, especially for individuals with family histories of T2D and related conditions. Second, the presence of these variants may predict responses to therapy ${ }^{16}$. T2D treatment is largely empirical and the prediction of specific responses to a therapeutic agent in any patient is difficult ${ }^{10}$. Patients with T2D and variants may respond differently to specific therapies, such as an insulin sensitizer, because HMGA1 variant IVS5-13insC defines a specific defect that decreases insulin receptor concentrations and insulin resistance. Third, individuals possessing functional HMGA1 variant IVS5-13insC and T2D may have different clinical courses from other patients with T2D, including differences in the development of complications. Fourth, the search for new therapies for T2D can include agents that upregulate HMGA1 expression. Finally, this conclusion provides some theoretical basis for HMGA1 single gene deletion- or mutation-induced insulin resistance as the underlying cause of T2D. Furthermore, IVS5-13insC can be regarded as a novel target of gene therapy for T2D and insulin resistance.

The exact biological mechanism underlying the association between the HMGA1 gene and risk of T2D remains uncertain. Functional studies and succeeding replications of these associations are necessary to define the potential role of the HMGA1 variant IVS5-13insC in predicting 
T2D developments. Although the current study provides this conclusion, further studies on HMGA1 are warranted to clarify the role of this gene in diabetes pathogenesis.

HMGA1 has been extensively investigated. A study demonstrate that a relationship exists between the HMGA1 IVS5-13insC and AMI, suggesting that defects at the HMGA1 may play a pathogenetic role in AMI, in the absence of T2D and other cardiovascular risk factors $^{17}$. Besides, HMGA1 is highly expressed in tumor cells; furthermore, HMGA1 is implicated in tumor initiation and progression by disrupting the stability of mitochondrial genome or by participating in the transcriptional regulation of gene expression related to tumors ${ }^{18}$. Thus, accurate physiological characteristics of HMGA1 polymorphism should be determined through several approaches.

\section{Declaration of conflict of interest}

We declare that there are no financial or other potential conflicts of interest, and there is no conflict of interest that could be perceived as prejudicing the impartiality of the research reported.

\section{Acknowledgments}

The Natural Scientific Foundation of Chinese Shandong Province (ZR2015CL019, ZR2014CM046) and the Technology Development Project Plan of Shandong Education Department (J17KB090 \& J17KA102) offered the grants for this work.

\section{References}

1. Zhang P, Zhang X, Brown J, Vistisen D, Sicree R, Shaw J,Nichols G. Global healthcare expenditure on diabetes for 2010 and 2030. Diabetes Res Clin Pract. 2010; 87(3): 293-301.

2. Herder C, Roden M. Genetics of type 2 diabetes: pathophysiologic and clinical relevance. Eur J Clin Invest. 2011; 41(6): 679-692.

3. Voight BF, Scott LJ, Steinthorsdottir V, Morris AP, Dina C, Welch RP,Zeggini E, Huth C, Aulchenko YS, Thorleifsson G, McCulloch LJ, Ferreira T, Grallert H, Amin N, Wu G, Willer CJ, Raychaudhuri S, McCarroll SA, Langenberg C, Hofmann OM, Dupuis J, Qi L, Segre AV, van Hoek M, Navarro P, Ardlie K, Balkau B, Benediktsson R, Bennett AJ, Blagieva R, Boerwinkle E, Bonnycastle LL, Bengtsson Bostrom K, Bravenboer B, Bumpstead S, Burtt NP, Char- pentier G, Chines PS, Cornelis M, Couper DJ, Crawford G, Doney AS, Elliott KS, Elliott AL, Erdos MR, Fox CS, Franklin CS, Ganser M, Gieger C, Grarup N, Green T, Griffin S, Groves CJ, Guiducci C, Hadjadj S, Hassanali N, Herder C, Isomaa B, Jackson AU, Johnson PR, Jorgensen T, Kao WH, Klopp N, Kong A, Kraft P, Kuusisto J, Lauritzen T, Li M, Lieverse A, Lindgren CM, Lyssenko V, Marre M, Meitinger T, Midthjell K, Morken MA, Narisu N, Nilsson P, Owen KR, Payne F, Perry JR, Petersen AK, Platou C, Proenca C, Prokopenko I, Rathmann W, Rayner NW, Robertson NR, Rocheleau G, Roden M, Sampson MJ, Saxena R, Shields BM, Shrader P, Sigurdsson G, Sparso T, Strassburger K, Stringham HM, Sun Q, Swift AJ, Thorand B, Tichet J, Tuomi T, van Dam RM, van Haeften TW, van Herpt T, van Vliet-Ostaptchouk JV, Walters GB, Weedon MN, Wijmenga C, Witteman J, Bergman RN, Cauchi S, Collins FS, Gloyn AL, Gyllensten U, Hansen T, Hide WA, Hitman GA, Hofman A, Hunter DJ, Hveem K, Laakso M, Mohlke KL, Morris AD, Palmer CN, Pramstaller PP, Rudan I, Sijbrands E, Stein LD, Tuomilehto J, Uitterlinden A, Walker M, Wareham NJ, Watanabe RM, Abecasis GR, Boehm BO, Campbell H, Daly MJ, Hattersley AT, Hu FB, Meigs JB, Pankow JS, Pedersen O, Wichmann HE, Barroso I, Florez JC, Frayling TM, Groop L, Sladek R, Thorsteinsdottir U, Wilson JF, Illig T, Froguel $\mathrm{P}$, van Duijn CM, Stefansson K, Altshuler D, Boehnke M, McCarthy MI. Twelve type 2 diabetes susceptibility loci identified through large-scale association analysis. Nat Genet: 2010; 42(7): 579-589.

4. Goldfine ID. The insulin receptor: molecular biology and transmembrane signaling. Endocr Rev: 1987; 8(3): 235255.

5. Bustin M, Reeves R. High-mobility-group chromosomal proteins: architectural components that facilitate chromatin function. Prog Nucleic Acid Res Mol Biol: 1996; 54(35-100.

6. Foti D, Chiefari E, Fedele M, Iuliano R, Brunetti L, Paonessa F, Manfioletti G, Barbetti F, Brunetti A, Croce CM, Fusco A. Lack of the architectural factor HMGA1 causes insulin resistance and diabetes in humans and mice. Nat Med: 2005; 11(7): 765-773.

7. Liu L, Ding H, Wang HR, Xu YJ, Cui GL, Wang PH, Yuan G, Yu XF, Wang DW. Polymorphism of HMGA1 is associated with increased risk of type 2 diabetes among Chinese individuals. Diabetologia: 2012; 55(6): 1685-1688.

8. Chiefari E, Tanyolac S, Paonessa F, Pullinger CR, Capula C, Iiritano S, Mazza T, Forlin M, Fusco A, Durlach 
V, Durlach A, Malloy MJ, Kane JP, Heiner SW, Filocamo M,Foti DP, Goldfine ID, Brunetti A. Functional variants of the HMGA1 gene and type 2 diabetes mellitus. JAMA: 2011; 305(9): 903-912.

9. Pullinger CR, Goldfine ID, Tanyolac S, Movsesyan I, Faynboym M, Durlach V, Chiefari E, Foti DP, Frost PH, Malloy MJ, Brunetti A, Kane JP. Evidence that an HMGA1 gene variant associates with type 2 diabetes, body mass index, and high-density lipoprotein cholester$\mathrm{ol}$ in a Hispanic-American population. Metab Syndr Relat Disord: 2014; 12(1): 25-30.

10. Karnes JH, Langaee TY, McDonough CW, Chang SW,Ramos M, Catlin JR, Jr.,Casanova OE,Gong Y,Pepine CJ,Johnson JA,Cooper-Dehoff RM. Lack of association of the HMGA1 IVS5-13insC variant with type 2 diabetes in an ethnically diverse hypertensive case control cohort. J Transl Med: 2013; 11(12.

11. Marquez M, Huyvaert M, Perry JR, Pearson RD, Falchi M, Morris AP, Vivequin S, Lobbens S, Yengo L, Gaget S, Pattou F, Poulain-Godefroy O, Charpentier G, Carlsson LM, Jacobson P, Sjostrom L, Lantieri O, Heude B, Walley A, Balkau B, Marre M, Froguel P, Cauchi S. Low-frequency variants in HMGA1 are not associated with type 2 diabetes risk. Diabetes: 2012; 61(2): 524-530.

12. Wells G, Shea B, O'Connell D, Peterson J, Welch V, Losos M, Tugwell P. The Newcastle-Ottawa Scale (NOS) for Assessing the Quality of Non-Randomized Studies in Meta-Analysis. Applied Engineering in Agriculture: 2014; 18(6): 727-734.
13. Chiefari E, Tanyolac S, Iiritano S, Sciacqua A, Capula C, Arcidiacono B, Nocera A, Possidente K, Baudi F, Ventura V, Brunetti G, Brunetti FS, Vero R, Maio R, Greco M, Pavia M, Hodoglugil U, Durlach V, Pullinger CR, Goldfine ID, Perticone F, Foti D, Brunetti A. A polymorphism of HMGA1 is associated with increased risk of metabolic syndrome and related components. Sci Rep: 2013; 3(1491.

14. Bianco A, Chiefari E, Nobile CG, Foti D, Pavia M, Brunetti A. The Association between HMGA1 rs146052672 Variant and Type 2 Diabetes: A Transethnic Meta-Analysis. PLoS One: 2015; 10(8): e0136077.

15. Hale PJ, Lopez-Yunez AM, Chen JY. Genome-wide meta-analysis of genetic susceptible genes for Type 2 Diabetes. BMC Syst Biol: 2012; 6 Suppl 3(S16.

16. Smith RJ, Nathan DM, Arslanian SA, Groop L, Rizza RA, Rotter JI. Individualizing therapies in type 2 diabetes mellitus based on patientcharacteristics: what we know and what we need to know. J Clin Endocrinol Metab: 2010; 95(4): 1566-1574.

17. De Rosa S, Chiefari E, Salerno N, Ventura V, D'Ascoli GL, Arcidiacono B, Ambrosio G, Bilotta FL, Torella D, Foti D, Indolfi C, Brunetti A. HMGA1 is a novel candidate gene for myocardial infarction susceptibility. Int J Cardiol: 2017; 227(331-334.

18. Mao L, Wertzler KJ, Maloney SC, Wang Z, Magnuson NS, Reeves R. HMGA1 levels influence mitochondrial function and mitochondrial DNA repair efficiency. Mol Cell Biol: 2009; 29(20): 5426-5440. 